\title{
Globalization, the Rule of (Administrative) Law, and the Realization of Democratic Governance in Africa: Realities, Challenges, and Prospects
}

Migai Akech

University of Nairobi, amigai@uonbi.ac.ke

Follow this and additional works at: https://www.repository.law.indiana.edu/ijgls

Part of the Administrative Law Commons, Comparative and Foreign Law Commons, and the International Law Commons

\section{Recommended Citation}

Akech, Migai (2013) "Globalization, the Rule of (Administrative) Law, and the Realization of Democratic Governance in Africa: Realities, Challenges, and Prospects," Indiana Journal of Global Legal Studies: Vol. 20 : Iss. 1 , Article 12.

Available at: https://www.repository.law.indiana.edu/ijgls/vol20/iss1/12

This Symposium is brought to you for free and open access by the Law School Journals at Digital Repository @ Maurer Law. It has been accepted for inclusion in Indiana Journal of Global Legal Studies by an authorized editor of Digital Repository @ Maurer Law. For more information, please contact rvaughan@indiana.edu. 


\title{
Globalization, the Rule of (Administrative) Law, and the Realization of Democratic Governance in Africa: Realities, Challenges, and Prospects
}

\author{
MigAJ AKECH*
}

\begin{abstract}
This article reviews the impact of globalization on democracy in Africa. It sees globalization, which has largely taken the shape of neoliberalism, as leading to the development of a minimalist conception of democracy in African countries. Further, this article contends that administrative law norms, which are increasingly embraced in Constitutions and judicial decisions world over, can be useful instruments for deepening democracy in Africa. That is, the establishment and implementation of elaborate regimes of administrative law (containing principles, procedures, and remedies that circumscribe the exercise of both public and private power) can contribute to the realization of democratic governance in African countries. This article then demonstrates how administrative law can subject the exercise of power to the rule of law, contribute to the realization of social and economic rights, enhance public participation in governance, and contribute to the democratization of the exercise of power within legislatures and judiciaries.
\end{abstract}

\section{INTRODUCTION}

It is fair to say that globalization, which has been defined as the intensification of the process of international interdependence, ${ }^{1}$ has

${ }^{\star}$ Associate Professor, School of Law, University of Nairobi.

1. See, e.g., David S. Law, Globalization and the Future of Constitutional Rights, 102 Nw. U. L. REV. 1277, 1278 (2008) (defining globalization as a process by which 'technological, economic, and political innovations ... have drastically reduced the barriers to economic, political and cultural exchange,' resulting in not only 'increasing transnational flows and increasingly thick networks of interdependence,' but also an expansion of the 'scale on which power is organized and exercised.") (citations omitted).

Indiana Journal of Global Legal Studies Vol. 20, Issue 1 (2013)

(C) Indiana University Maurer School of Law 
contributed to the growth of democracy in Africa in the last two decades. Here, the ideology of neoliberalism espoused by the World Bank and the International Monetary Fund (IMF) in their structural adjustment programs (SAPs) has been the main instrument of globalization. Through SAPs, which were introduced in the early 1980s, African countries were told that they could only enhance their development by increasing the role of the market in their economies. The ensuing marketization process mandated reducing the size of the public sector, including privatizing public enterprises, and removing government regulations and controls. ${ }^{2}$

A decade or so after the inception of SAPs, however, it became quite clear that the objectives of the neoliberal market reforms would not be realized in the absence of complementary political reforms. Market reforms invariably ran up against determined political resistance, as they constituted a threat to the authoritarian regimes that profited from the status quo and, in particular, sought to maintain public enterprises as sources of patronage resources. ${ }^{3}$ Hence, a consensus emerged among Africa's reformers and the Bretton Woods Institutions during the late 1980 s and the early 1990 s that market reforms could only be implemented "by establishing mechanisms of accountability and subjecting governmental operations to public scrutiny." 4 It was hoped that the transition to multiparty democracy would enable Africans to "scrutinize the performance of their governments and change [them] if necessary." 5 Accordingly, the World Bank and the IMF began to condition aid on the adoption of programs for both political and economic adjustment. The political adjustment programs were later subsumed under the rubric "good governance." Indeed, many commentators considered the adoption of multiparty democracy and economic reforms in the early 1990 s to be heralds of Africa's renaissance. Such was the optimism that the two policies were dubbed "[t]he twin pillars of [Africa's] second liberation." 6

2. See, e.g., E. A. Brett, States, Markets and Private Power: Problems and Possibilities, in Privatisation In Less Developed CounTries 47, 49 (Paul Cook \& Colin Kirkpatrick eds., 1988) ("[T]he interventions of the World Bank and the IMF, produced overwhelming pressures to reduce the role of the state and to sell loss-making public corporations into the private sector where it was assumed that they would be rehabilitated by being subjected to the discipline of the market.").

3. See Joel D. Barkan, Divergence and Convergence in Kenya and Tanzania: Pressures for Reform, in BEYOND CAPITALISM vs. Socialism IN KENYA AND TANZANIA 1, 1-2 (Joel D. Barkan ed., 1994).

4. Id. at 2 .

5. Id.

6. Id at 1. 
Democratization, which largely took the form of constitutional reform and the introduction of multiparty democracy, therefore became a key agenda of neoliberalism. Since 1990, these democratization initiatives have led to significant political reforms in many African countries. Key achievements of these initiatives have included: the reintroduction of multiparty politics, the introduction and sustenance of presidential term limits, the institution of regular and competitive elections for legislative and presidential office, the liberation of legislatures and judiciaries from the shackles of the executive, and the emergence and growth of an assertive private media and civil society. Further, if the respect of presidential term limits is taken as an indicator of adherence to the rule of law, then it follows that constitutional rules are increasingly taken more seriously. Accordingly, Africa's democracy picture is beginning to look decent and presentable. Compared to 1990, when just three countries could be called democracies, Freedom House reports that Africa is now home to twenty-four democracies. ${ }^{7}$ In addition, the African public is increasingly demanding and appreciating democracy; it perceives democracy in terms of protecting civil liberties, participating in decision-making, voting in elections, and implementing governance reforms. In this respect, it is encouraging that technological changes, such as the proliferation of mobile phones, have made citizens more aware of civic matters. ${ }^{8}$

However, various critics have questioned the nature of the democracy that African countries have adopted as a result of the above global processes. Nqosa L. Mahao, for example, argues that "neo-liberal globalisation has consciously crafted a minimalist concept of democracy," which "provides for elected government . . [ [but] constrains and emasculates participatory democracy, the centrality of social justice in the mission of the state and state sovereignty." As we shall see, Africa's privatization experience supports this view. ${ }^{10}$

Further, although neoliberal globalization has played a central part in advancing multipartyism in Africa, it may have also "actively imped[ed] further democratization."11 For example, Stephen Brown has

7. Larry Diamond, The Rule of Law Versus the Big Man, 19 J. DEMOCRACY 138, 139 (2008).

8. See, e.g., Larry Diamond, Liberation Technology, 21 J. DEMOCRACY 69 (2010).

9. See, e.g., Nqosa L. Mahao, The Constitutional State in the Developing World in the Age of Globalisation: From Limited Government to Minimum Democracy, 12 LaW, DEMOCRACY \& DEV., no. 2, 2008 at 1, 2 (emphasis added).

10. See infra Part III.A.

11. Stephen Brown, Authoritarian Leaders and Multiparty Elections in Africa: How Foreign Donors Help to Keep Kenya's Daniel arap Moi in Power, 22 THIRD WORLD Q. 725, 725 (2001). 
argued that, in Kenya,"[d]onors twice knowingly endorsed unfair elections (including suppressing evidence of their illegitimacy) and repeatedly undermined domestic efforts to secure far-reaching political reforms." 12 In his view, donors acted in this manner because their "primary concern appeared to be the avoidance of any path that could lead to a breakdown of the political and economic order, even if this meant legitimising and prolonging the regime's authoritarian rule."13 Similarly, in Uganda in the 1990s, the World Bank ignored corrupt practices because it was more concerned with achieving progress in "privatization and other areas of structural adjustment." 14 In addition, Graham Harrison has observed that donors have tended to downplay the corrupt practices of recipient governments since dealing with them would disrupt the postconditionality regime. ${ }^{15}$ Therefore, it appears that the World Bank has primarily been interested in the continuation of its programs even when they may have undermined the public interest of attaining democratic governance.

Accordingly, the democracy espoused in Africa today is largely narrow or minimalist, and is primarily attached to the ballot box; but democracy should be a daily practice rather than a periodic event. Since the right to be consulted when political decisions or choices are being made is a core component of democracy, democratization initiatives will remain hollow if they are not accompanied by mechanisms that enable citizens to participate meaningfully in the daily practices of governance. In particular, because periodic elections do not offer the electorate an adequate degree of control over government, there is a need for auxiliary political and legal mechanisms to ensure not only the day-to-day participation by citizens in governance, but also the political accountability of the agents and instruments of governance. In other words, there is a need to deepen the ways in which ordinary Africans can effectively participate in and influence policies and governmental actions that impact their lives. This is particularly the case given that much of the work of government has been, and continues to be, delegated to various public and private agencies thanks to neoliberal globalization. In addition, a number of transnational organizations, such as those regulating international sports, now exercise immense

12. Id.

13. $I d$.

14. Roger Tangri \& Andrew Mwenda, Corruption and Cronyism in Uganda's Privatization in the 1990s, 100 AFR. AFF. 117, 130 (2001).

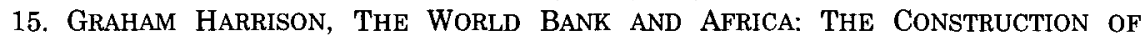
GOVERNANCE STATES 71 (2004) (describing the post-conditionality regime as one in which the donors no longer police reforms through the threat of freezing or withdrawing aid, but instead negotiate for reforms through partnership and participation). 
power that threatens or violates the liberties of individuals. A need also exists to regulate the power of these bodies.

Fortunately, many developed and developing countries have increasingly turned to administrative law as an instrument for deepening democracy. These countries have embraced administrative law norms such as legality, reasonableness, procedural fairness, and proportionality. They have also undertaken the duty to fulfill legitimate expectations as a mechanism for regulating the exercise of public, and even private, power. Arguably, the acceptance of these principles, which are recognized in many Constitutions and embraced in judicial decisions, constitutes the globalization of administrative law. This process is buttressed by the enactment of statutes that establish sets of minimum standards that governmental agencies must meet to ensure that their decisions and actions are procedurally fair. ${ }^{16}$ Further, many countries have established ombudsmen to investigate individual complaints of maladministration, correct errors and impropriety in such cases, and provide remedies to aggrieved citizens. Another encouraging development is that a number of jurisdictions have embraced novel remedies, such as the structural interdict, which ensure that judicial review contributes meaningfully to the realization of administrative justice. ${ }^{17}$

This article contends that administrative law can be a useful instrument for deepening democracy in Africa. That is, the establishment and implementation of elaborate regimes of administrative law (containing principles, procedures, and remedies that circumscribe the exercise of both public and private power) promise to contribute to the realization of democratic governance in African countries. Although administrative law is already impacting the exercise of power in countries such as South Africa, it needs to be accelerated in other African countries through administrative law reform. Part I provides a conceptual framework and examines globalization from the viewpoint of democracy and the rule of law. Part

16. See, e.g., Administrative Decisions (Judicial Review) Act 1977 (Austl.); Promotion of Administrative Justice Act 3 of 2000 (S. Afr.); Administrative Procedure Act, 5 U.S.C. $\S \S$ 500-596 (1946).

17. See, e.g., Christopher Mbazira, Litigating Socio-Economic Rights in South AFrica: A Cholce Between CoRrective AND Distributive Justice (2009). The structural interdict is in order of the court requiring the person to whom it is directed to do or refrain from doing a particular thing. In the context of the enforcement of social economic rights, it is often directed to government agencies and requires them to take positive steps to remedy a wrongful state of affairs for which they are responsible, for example, failing to give a hearing to persons affected by their decisions. Further, the court retains jurisdiction after issuing the interdict so that it can supervise the implementation of its orders. 
II considers how administrative law can enhance the quality of democracy in Africa. It demonstrates how administrative law can subject the exercise of power to the rule of law, contribute to the realization of social and economic rights, enhance public participation in governance, and contribute to the democratization of the exercise of power within legislatures and judiciaries. Part III concludes.

\section{Globalization, Administrative Law, AND DEMOCRACY}

Globalization, especially its neoliberal variant, is typically presented "as a value-free and inevitable force of modernisation." 18 Neoliberalism assumes that the operation of free markets will bring about a "natural community of interests." 19 In other words, the pursuit of one's own advantage will eventually benefit everyone, although the resulting benefits need not be distributed equally throughout society. Seeing globalization as "transnational processes of market-oriented governance," the dominant discourses limit discussion of this phenomenon to the extraterritorial, thereby neglecting its interactions with domestic political processes. ${ }^{20}$

But this neglect of the domestic "indicts democratic rule" within the nation-state. ${ }^{21}$ Democracy is predicated on popular sovereignty, which means "national political authorities are not only formally mandated to make key decisions but are also accountable to the citizenry for them." 22 However, globalization processes such as privatization undermine this logic since they preclude "the exercise of real national sovereignty and the implementation of truly democratic decisions by the people." 23 That is, these processes are producing a "democracy deficit," given that they not only encourage forms of governance that involve new uses of the private sector to achieve public ends, but also often bypass traditional public accountability mechanisms. ${ }^{24}$ As a result, globalization processes are eroding "the capacity of elected governments to ... [make] decisions

18. Mahao, supra note 9 , at 9-10.

19. Paul Williams \& Ian Taylor, Neoliberalism and the Political Economy of the 'New' South Africa, 5 NEW POL. ECON. 21, 22-24 (2000).

20. Alfred C. Aman, Jr., Globalization from the Ground $U_{p}$ : A Domestic Perspective, in The ImPact of Globalization on the UnITEd STATES, Volume 2: LAW AND GovernanCE 3,3 (Beverly Crawford ed., 2008).

21. Mahao, supra note 9 , at 11.

22. Id.

23. Id. at 12.

24. Alfred C. Aman, Jr., The Limits of Globalization and the Future of Administrative Law: From Government to Governance, 8 IND. J. GLOBAL LEGAL STUD. 379, 383 (2001). 
affecting their own citizens." 25 In any case, the technocratic agencies, such as regulatory authorities making decisions on behalf of governments, are often unaccountable. Furthermore, the public does not usually participate meaningfully when public functions are outsourced to the private sector, while vulnerable populations are often not involved at all. 26

In Africa, globalization processes have been blamed for exacerbating poverty, thereby undermining the prospect that meaningful democracy will be realized in the near future. Critics of privatization raise various objections. First, they contend that privatization has led to layoffs and worsening labor conditions. ${ }^{27}$ Second, they argue that even where privatization has enhanced enterprise efficiency, the bulk of its benefits have accrued to a privileged few-owners of capital and the political elite-while its costs have been borne by the majority such as consumers and workers-thereby worsening their welfare. ${ }^{28}$ Meaningful democracy cannot be obtained in such unequal socio-economic contexts. For this reason, socialist critiques of liberal theory have long maintained that individual liberty involves having an opportunity for self-realization, and even presupposes its achievement.29 That is, freedom should be positive in the sense of having the resources, powers, or abilities needed for the achievement of self-realization. ${ }^{30}$ The practice of democracy may therefore require the constitutional recognition of social and economic rights, and the imposition of a duty on the state to facilitate their realization. When the state fulfills this obligation, it contributes to the realization of economic equality and social justice, without which there can be no positive freedom and, equally, no meaningful democracy.

Therefore, a need arises to examine how globalization processes and domestic politics interact, if only to enhance the democratic control of the former. In Africa's case, this entails rethinking the minimalist model of democracy adopted thus far, with a view to establishing modes of direct democracy and other mechanisms that would give citizens some meaningful control over globalization processes. In this respect, Mahao takes the view that embedding cooperative governance, by which he means "direct citizens' participation in government along with

25. Robin Luckham, Are There Alternatives to Liberal Democracy?, in THE DEMOCRATIC DEVELOPMENTAL STATE 306, 307 (Mark Robinson \& Gordon White eds., 1998).

26. See Aman, supra note 20, at 15.

27. See, e.g., Sunita Kikeri \& John Nellis, An Assessment of Privatization, 19 WoRLD RES. BANK OBSERVER 87 (2004).

28. See, e.g., AdJustment with a Human Face: Protecting the Vulnerable and Promoting Grow'TH (Giovanni Andrea Cornia et al. eds., 1988).

29. See, e.g., JoHN GRAY, LIBERALISM 56 (2d ed. 1995).

30. See id. at 56-57. 
representative government," can enrich Africa's democratic project. ${ }^{31}$ This would entail allowing citizens, by way of constitutional prescriptions, to approve critical public issues through referenda. ${ }^{32} \mathrm{He}$ gives the example of the South African Constitution, which establishes "mechanisms of mandatory community or interest group consultations on matters directly affecting them." 33

Administrative law can be useful in the quest for auxiliary mechanisms of democratic control. Among other things, administrative law regulates the exercise of power by requiring that all administrative actions meet certain requirements of legality, reasonableness, and procedural fairness. It performs this function by setting out general principles and procedures that all administrators must follow and by providing remedies for people affected by administrative action. In the globalization context, scholars of administrative law have called for a new approach to the regulation of power. ${ }^{34}$

Although many jurisdictions have traditionally maintained a public-private distinction, according to which only the exercise of public power should be subjected to public law values, a new view is now emerging. According to this new view, the exercise of power, whether public or private, which affects vital interests, should comply with the principles of fair or considerate decision-making. In this regard, Alfred C. Aman, Jr. has argued that public-private partnerships should be viewed as an extension of the state, since "the delegation of public functions to private actors represents new ways for states to carry out their responsibilities." ${ }^{35}$ From this perspective, markets constitute a form of regulation, and "public law values . . . remain relevant, even though private actors now carry out various tasks that can be appropriately called governmental." 36 In his view, the challenge for administrative law is to determine "how best to conceptualize public-private relationships not only to assure fairness for those affected by these decisions, but information that will enable [citizens] to assess how best to determine whether these new arrangements are working and are workable from a democratic point of view." 37

31. Mahao, supra note 9 , at $\mathbf{1 5 .}$

32. See id.

33. Id.

34. See, e.g., Richard B. Stewart, Administrative Law in the Twenty-First Century, 78 N.Y.U. L. REV. 437 (2003).

35. Aman, supra note 24, at 382.

36. Id.

37. Alfred C. Aman, Jr., Privatization and the Democracy Problem in Globalization: Making Markets More Accountable Through Administrative Law, 28 FoRDHAM URB. L.J. 1477, 1498 (2001). 
This emerging approach requires administrative law to expand the democratic space by establishing institutional frameworks for the participation of citizens in public decision-making. In this regard, Jody Freeman has provided a useful framework for governmental regulation of privatization processes. She argues that instead of seeing privatization as a means of shrinking government, we should "imagine it as a mechanism for expanding government's reach into realms traditionally thought private." 38 She views privatization as "a means of 'publicization,' through which private actors increasingly commit themselves to traditionally public goals as the price of access to lucrative opportunities to deliver goods and services that might otherwise be provided directly by the state." 39 In practice, publicization would include giving the citizenry third party rights in privatization contracts. ${ }^{40}$

Above all, the dominance of neoliberalism now requires administrative law to confront private power. A core purpose of law is to protect individuals and groups against the exercise of power, be it public or private. While duties of considerate decision-making have been imposed on public or governmental bodies in most common law countries without much controversy and increasingly on private bodies exercising public or governmental functions with fading resistance, ${ }^{41}$ the idea of imposing them on purely private bodies exercising de facto power remains fiercely contested in many jurisdictions. Nevertheless, various administrative law scholars have advocated the view that when a body, whether public or private, wields "institutional power capable of affecting rights and interests," it ought to be subject to judicial review. ${ }^{42}$ According to this enlightened view, in determining whether to extend their supervisory jurisdiction to such private bodies, courts should look into factors such as the nature of interests affected by their decisions, how seriously their decisions impact those interests, "whether the affected interests have any real choice but to submit to the bod[ies'] jurisdiction[s], and the nature of the context in which the bod[ies] operate[."43

Arguing in favor of this progressive view in the English context, Dawn Oliver asserts that there is now a "broad common law duty of

38. Jody Freeman, Extending Public Law Norms Through Privatization, 116 HARV. L. REV. 1285, 1285 (2003).

39. Id.

40. See id. at 1317.

41. See id. at 1289 .

42. E.g., Murray Hunt, Constitutionalism and the Contractualisation of Government in the United Kingdom, in THE PROVINCE of ADMINISTRATIVE LAW 21, 32-33 (Michael Taggart ed., 1997).

43. Id. at 32 . 
considerate decision-making, the exact content of which will depend upon the circumstances, but which spans the public/private divide." 44 The corollary of this duty is a "right of those seriously affected by decisions taken by powerful bodies to have the effects of a decision upon them considered and taken into account fairly and rationally before the decision is made." 45 In Oliver's view, "duties of fairness and rationality in decision making" are common to both public and private law, and their existence should not "depend upon the question whether the body in question is public or private or performing public or governmental functions." 46 This view is further supported by Sir Stephen Sedley, who asserts, "the law's chief concern about the use of power is not who is exercising it but what the power is and whom it affects." 47

Nevertheless, these scholars caution that the mere fact that a private body possesses institutional power "should not lead inexorably to the conclusion that all principles of a public law nature should be equally applicable to such bodies." 48

\section{AdMINISTRATIVE LAW AND THE FUTURE OF DEMOCRACY IN AFRICA}

In assessing whether administrative law can enhance the quality of Africa's democracy, it is good to start by examining what role administrative law could play in regulating globalization processes such as privatization, and evaluate whether it has done so. If administrative law is so critical to democratic governance, why has it not been embraced by African countries? This entails an examination of the history of administrative law in Africa. There have also been encouraging developments that could enhance the future role of administrative law in governance. These developments include the constitutionalization and implementation of the right to fair administrative action and social and economic rights in several countries; and the establishment of institutions of horizontal accountability such as ombudsmen, human rights bodies, and anticorruption authorities. Another encouraging development is that African legislatures and judiciaries are becoming institutions of genuine

44. Dawn Oliver, Common Values in Public and Private Law and the Public/Private Divide, 1997 PuB. L. 630, 638.

45. Id.

46. Dawn Oliver, Common Values and the Public-Private Divide 89 (1999).

47. StePhen SedLey, Public Power and Private Power, in Freedom, LaW ANd Justice 19, 38 (1999).

48. Paul Craig, Public Law and Control over Private Power, in THE Province OF ADMINISTRATIVE LAW, supra note 42, at 196, 211. 
countervailing power, thanks to constitutional reforms. ${ }^{49}$ However, there are concerns of abuse of power within these institutions. Here too, administrative law can contribute to the democratization of the exercise of power, which will be necessary if these institutions are to play their roles effectively and legitimately. Finally, there has been an emergence of private power, which is primarily expressed in the context of privatization, but can also be observed in other domains, such as sports. Again, administrative law can contribute to the regulation of such private power.

\section{A. Public Law and Privatization in Africa ${ }^{50}$}

In democratic societies, the law should regulate both the power of government to privatize, and the power that private entities acquire by virtue of privatization processes. Law performs this critical function by making sure that the exercise of power is democratic, in that it is participatory and accountable. Unfortunately, policy-makers in Africa have not paid sufficient attention to the role of law in regulating privatization processes. This failure can be attributed to two political economy practices, which have dictated the formulation and implementation of neoliberal policies in Africa. These practices are neopatrimonialism and development assistance. ${ }^{51}$ Both tend to eschew law and work to ensure that privatization continues to take place in a context characterized by weak state institutions, including law. In addition, both practices work to ensure that the state does not regulate privatization processes in a democratic manner.

Neopatrimonialism refers to "a hybrid political regime in which informal patron-client relationships both underlie and overshadow legal-rational norms." ${ }^{52}$ This regime is undesirable since it abhors the establishment of effective state institutions, as these would greatly undermine the dispensation of clientelism and patronage. Informalism is the rule of the game. Thus, while the state appears to possess "all the trappings of a Weberian rational-legal system, with a clear distinction between the public and the private[,] ... this official order is constantly

49. See generally Legislative POWER IN EMERging AFRICAN Democracies (Joel D. Barkan ed., 2009) (documenting the emergence of legislatures in several African countries).

50. See generally Migai AKech, Privatization and Democracy in East AFrica: The Promise of AdMinistrative LAW (2009).

51. Id. at 23-31.

52. Migai Akech, Constraining Government Power in Africa, 22 J. DEMOCRACY 96, 96 (2011). See also S. N. Eisenstadt, Traditional Patrimonialism and Modern NEOPATRIMONIALISM 13 (1973) (discussing the aspects of neopatrimonial regimes). 
subverted by a patrimonial logic, in which officeholders almost systematically appropriate public resources for their own uses." 53 Therefore, in reality, the public sector in a neopatrimonial system is appropriated by private interests and, as a result, there is widespread "straddling between positions [and] practices of power and economic accumulation." ${ }^{4}$ Since the neopatrimonial system can only work where the state apparatus is not properly or completely institutionalized, ruling elites have an incentive to perpetuate the weakness of the state apparatus. ${ }^{55}$ Indeed, the ruling elites are often apprehensive about strong institutionalization of the state apparatus because it may lead to elements of the state bureaucracy developing their own independent agendas, thereby threatening regime survival. ${ }^{56}$ Further, while the ruling elites may understand that "an efficient, independent (from political pressure) and meritocratic state bureaucracy is needed to implement national development policies," they are unlikely to create such a bureaucracy since it "would be less pliable and politically reliable and more likely to expose malfeasance." 57

Governance in African countries continues to be characterized by widespread patrimonial penetration of the legal-rational bureaucracy, which is in turn defined by grants of broad swaths of power that are not sufficiently regulated by law. Further, the legal-rational domain itself is not sufficiently participatory or accountable. This results in legal-rational systems-with their already broad grants of power-that are subject to penetration by patrimonial forces bent on self-serving rather than public regarding outcomes. Neopatrimonialism also entails the usurpation of public resources by political elites. The elites then dispense these public resources as political patronage for purposes of retaining political power. In my estimation, neopatrimonial considerations have considerably influenced privatization processes in African countries. Again, the World Bank and the IMF have typically

53. Nicolas van de Walle, african Economies and the Politics of Permanent CRISIS, 1979-1999, at 51-52 (2001).

54. Béatrice Hibou, The 'Privatization' of the State: North Africa in Comparative Perspective, in The Dynamics of States: The Formation and Crises of STate DOMINATION 71, 91 (Klaus Schlichte ed., 2005).

55. See Patrick Chabal \& Jean-Pascal Daloz, AFrica Works: Disorder as POLITICAL INSTRUMENT 14 (1999).

56. See William Reno, The Privatisation of Sovereignty and the Survival of Weak States, in Privatizing The STATE 95, 98 (Béatrice Hibou ed., Jonathan Derrick trans., 2004).

57. Diana Cammack, The Logic of African Neopatrimonialism: What Role for Donors?, 25 DEv. PoL'Y REv. 599, 601 (2007). 
insisted on the implementation of neoliberal reforms as a precondition for the receipt of development assistance. ${ }^{58}$

Conversely, development assistance is troubling because it undermines institution building, thereby reinforcing the neopatrimonial tendencies of African governments. ${ }^{59}$ In the first place, the preference of international development agencies such as the World Bank and the IMF for quick, technocratic, but undemocratic decision-making in the formulation and implementation of neoliberal policies (such as privatization) has played into the hands of African governments, which have been keen to maintain the flow of patronage resources. In the absence of open and democratic institutional frameworks, privatization initiatives have often benefited powerful state and economic elites at the expense of the general public. For example, "Uganda's privatization in the 1990s was marred by malpractices and manipulations involving regime politicians and well-connected individuals."60 Accordingly, governments in Africa have been assisted greatly by the lack of democracy in the neoliberal reform process, which has allowed them to manipulate the process to serve their narrow interests. As Roger Tangri and Andrew Mwenda have observed, "World Bank-designed divestiture programmes in African countries often conferred wide discretion on state elites, partly to quicken the pace of privatization and partly to counter resistance to it." 61 Oliver Campbell and Anita Bhatia confirm this observation, noting that there was "pressure to proceed to privatize and to deal with regulation afterward." 62

These two practices have facilitated a culture of secrecy in the formulation and implementation of privatization processes that are also characterized by straddling - by internal and external actors-between the public and private realms. In the area of security, for example, clandestine power networks of African elites and private security and military companies linked to multinational corporations have conspired to exploit the continent's natural resources and the commercial opportunities offered by the privatization of security. ${ }^{63}$ Even where they have cut down on military strengths, in keeping with the neoliberal agenda, African political elites have, in some cases, established private security groups to protect their regimes. These privatizations often take

58. See, e.g., JoHN DEgnBol-MartinUssen \& POUL ENGBERG-PEDERSON, AID: UNDERSTANDING INTERNATIONAL DEVELOPMENT COOPERATION (2003); John Brohman, Universalism, Eurocentrism, and Ideological Bias in Development Studies: From Modernisation to Neoliberalism, 16 THIRD WORLD Q. 121 (1995).

59. See VAN DE WALLE, supra note 53, at 59-60.

60. Tangri \& Mwenda, supra note 14 , at 117.

61. Id, at 132 .

62. Oliver Campbell White \& Anita Bhatia, Privatization in Africa 48 (1998).

63. See AKECH, supra note 50, at 93-103. 
place outside the law, and are prevalent in countries such as Angola, Sierra Leone, Uganda, and Kenya. ${ }^{64}$

Another plausible explanation for the neglect of legal reform issues has been the failure to acknowledge the legal consequences of the acquisition of significant power by private bodies as a result of privatization processes. In turn, this failure can be attributed to a liberal mind-set, which mostly seeks to regulate public power and largely considers private power to be benign. For example, public law in common law countries is only designed to regulate the exercise of "public power"-that is, the power of government-as opposed to "private power." In these jurisdictions, the law's relationship with power has largely been governed by the ideology of liberal theory, which establishes a dichotomy between the public sphere and the private sphere. On the one hand, liberal theory explicitly recognizes the imbalances in power between public bodies and private individuals, which is then seen to justify the imposition of "higher order duties" of fair or considerate decision-making on public bodies. ${ }^{65}$ Conversely, liberal theory does not sufficiently recognize power imbalances in the private domain and largely assumes that individuals are equal and capable of resolving any instances of abuses of private power among themselves, without the need for governmental intervention. While liberal theory has evolved over the years, culminating in the establishment of the regulatory state in many developed countries, ${ }^{66}$ fidelity to the public-private dichotomy continues to be a hindrance to the imposition of certain higher order duties on private bodies.

For example, the orthodox view is that constitutional rights "impose constitutional duties . . . only on the government and not on private actors."67 According to liberal theory, it is desirable to maintain "a public-private division in the scope of constitutional rights, leaving the private sphere free from constitutional regulation."68 It is asserted that this limitation of "the scope of constitutional rights to the public sphere enhances the autonomy of citizens, preserving a heterogeneous private sphere free from the uniform and compulsory regime constructed by constitutional norms." 69 The orthodox view is arguably inadequate in today's globalizing world given that private bodies now wield significant

64. See id.

65. OLIVER, supra note 46 , at 32 .

66. See, e.g., CASS R. Sunstein, AFter the Rights Revolution: RECONCEIVING the REGULATORY STATE 11 (1990).

67. Stephen Gardbaum, The "Horizontal Effect" of Constitutional Rights, $102 \mathrm{MrCH}$. L. REV. 387, 394 (2003).

68. Id.

69. Id. at $394-95$. 
power. Fortunately, a horizontal approach to constitutional rights is emerging, according to which "constitutional rights and values may be threatened by extremely powerful private actors and institutions as well as governmental ones."70 The horizontal approach criticizes the vertical approach for "automatically privileg[ing] the autonomy and privacy of such citizen-threateners over that of their victims." 71

The fact that the state has chosen to privatize a service does not relieve it of its obligations to its citizens. In this regard, it is useful to examine privatization from the viewpoint of the human rights obligations of the state. In particular, the development of a notion of "positive obligations" in human rights discourse, which requires the state to "respect, protect and fulfil" human rights, is particularly encouraging. ${ }^{72}$ This concept expresses the idea that "the state [has] a duty to take some positive action in order to ensure the effective enjoyment" of human rights. ${ }^{73}$ Further, the obligations imposed on the state by international human rights instruments include a duty to ensure effective public participation in decision-making and effective access to information. ${ }^{74}$ Accordingly, the state is required to ensure democratic governance if it is to meet its human rights obligations. From this perspective, the state will meet its human rights obligations by, among other things, establishing mechanisms that facilitate effective public participation in privatization decision-making. Further, the state will meet its human rights obligations by regulating the power of private actors performing public functions.

Again, while economists and political scientists have written much on the subject of privatization in African countries, ${ }^{75}$ legal scholars have not said much about its ramifications for democracy and constitutionalism. The explanation for this dearth of legal analysis of privatization lies in the fact that economists, whose concerns primarily revolve around questions of economic efficiency, have dominated the discourse on privatization. By and large, privatization has been

70. Id. at 395 .

71. Id.

72. E.g., Silvia Borelli, Positive Obligations of States and the Protection of Human Rights, 15 INTERIGHTS BULL. 101, 103 n.2 (2006).

73. Id. at 101 .

74. See, e.g., Human Rights and Privatization, AMNESTY INT'L 5 (17 Mar. 2005), http://www.amnesty.org/en/library/asset/POL34/003/2005/en/fe6b668d-d50f-11dd-8a23d58a49c0d652/pol340032005en.

75. See, e.g., Merilee S. Grindle, Challenging the State: Crisis and Innovation IN LATIN AMERICA AND AFrICA (1996); GRAHAM HARRISON, THE WoRLd BANK AND AFRICA: The Construction of Governance States (2004); Privatisation In Less Developed CounTries (Paul Cook \& Colin Kirkpatrick eds., 1988); PrIVAtising THE STATE (Béatrice Hibou ed., 2004). 
perceived as an exclusive preserve of economic technocrats that does not require public debate.

Due to these factors, insufficient attention has been paid to privatization's implications for democracy and constitutionalism in African countries. Yet privatization processes continue to distribute societal resources and regulate the lives of citizens. Therefore, it becomes important to ensure that political processes, such as privatization decision-making, are subject to legal regulation. Although administrative law could have helped in this endeavor, it is a tool that has been neglected, partly because of the prevalence of wide discretionary powers in the legal framework, and partly because of the reluctance of judiciaries to hold the exercise of such power to account.

\section{B. A Brief History of Administrative Law in Africa}

Despite the potential of administrative law to facilitate the democratic governance of globalization processes such as privatization, it has not been given serious attention in common law African countries. The explanation for this state of affairs is historical, and has much to do with the colonial legacy of autocracy. ${ }^{76}$ While these countries received administrative law as part of the general statutes by which the British imposed the common law on their African territories, the colonial administration concentrated all power in the governor. ${ }^{77}$ The received administrative law was rendered irrelevant "both because the grants of power to the governor were so broad as to confound the ultra vires rule, and because the sorts of decisions with which he was charged were largely 'executive' rather than 'quasi-judicial." 78 The ultra vires rule sought to ensure that public agencies to which power had been granted did not exceed their powers as defined by the enabling acts of Parliament. ${ }^{79}$ But where the enabling act of Parliament conferred very broad powers to an agency, as tended to be the case in British colonies, for example, defining the scope of an agency's powers was almost an impossible task. English courts drew a distinction between administrative and judicial or quasi-judicial proceedings, an approach that was followed in the colonies. The effect was that while the courts were willing to, and often did, intervene to regulate the exercise of power when an agency was engaged in judicial or quasi-judicial

76. See, e.g., MAHMOOD MAMDANI, CITIZEN AND SUBJECT: CONTEMPORARY AFRICA AND THE LEGACY OF LATE COLONIALISM (1996).

77. See Robert B. Seidman, Administrative Law and Legitimacy in Anglophonic Africa: A Problem in the Reception of Foreign Law, 5 LAW \& Soc'Y REV. 161, 175 (1970).

78. Id.

79. See P.P. Craig, Administrative Law 5 (5th ed. 2003). 
proceedings, they were markedly reluctant to intervene in administrative processes. ${ }^{80}$

As a result of these impediments, administrative law was rarely invoked to curb the powers of the governor and public agencies, which invariably were exercised through administrative proceedings. ${ }^{81}$ To make matters worse, the enforcement of administrative law remedies "depended upon private initiative through an adversary system." 82 However, the African majority could not access these courts, due to the duality of the colonial legal system that created a "civilized society" defined by the "civilized" laws that regulated the affairs of the civilized settler communities on the one hand, and a customary legal order that regulated the affairs of the natives on the other hand. ${ }^{83}$ While "[ $\left.t\right]$ he former was organized on the principle of differentiation to check the concentration of power, the latter [was organized] around the principle of fusion to ensure a unitary authority." ${ }^{4}$ In essence, the African majority had no rights in "civilized society," and was effectively debarred from seeking administrative law remedies against colonial maladministration. ${ }^{85}$

The inherited culture of autocracy still thrives today in these countries, despite the prevalence of democratization initiatives. These initiatives have tended to concentrate on enhancing ballot box democracy and constitutional reform targeted at deconcentrating the power of the executive by strengthening legislatures and judiciaries. What these reform initiatives have failed to grasp, however, is the fact that much of the power of government in African countries remains uncircumscribed. That is, statutory laws and regulations typically grant public officials broad powers without establishing effective procedural mechanisms or limiting principles to circumscribe their exercise. $\mathrm{H}$. Kwasi Prempeh thus observes that "[l]egislation . . . still routinely gives the African executive wide leeway ('as he thinks fit,' 'as he may prescribe') in the everyday exercise of authority granted by statute." 86

Africa's constitutional history also shows clearly that the culture of autocracy, which has long been personified by the imperial presidency, was carefully reconstructed as part of the reconstitution of the state by political elites in the decade immediately following the attainment of independence. "Between 1960 and 1962 [alone], thirteen newly

80. See id. at 10 .

81. See Seidman, supra note 77 , at 178 .

82. Id. at 193.

83. See MAMDANI, supra note 76 , at $16-23$.

84. Id. at 18.

85. See id.

86. H. Kwasi Prempeh, Presidents Untamed, J. DEMOCRACY, April 2008, at 109, 115. 
independent African states, beginning with [Nkrumah's] Ghana, amended or replaced their independence constitutions" in favor of new "rules of the game" that centralized public power in a unitary president. ${ }^{87}$ This reconstitution of the state was informed by an instrumental view of law that saw the primary purpose of the Constitution as facilitating state power, not controlling it.88 For example, Julius Nyerere of Tanzania argued that Africa needed Constitutions that would enable "the executive to function without being checked at every turn." 89 Therefore, according to these elites, law "needed to be an accelerator, not a brake, to national development goals." 90 Contrary to their expectations, the Constitutions that they were "forced" to adopt by the departing colonial administrations had fragmented power considerably, through mechanisms such as bicameral legislatures, federalism or regionalism, separation of powers, judicial review of legislative and executive action, and bills of rights which created a framework for multi-party democracy, among other things. ${ }^{91}$

It should be noted that these political elites' instrumental view of law was informed by "power realities" in the colonial state. ${ }^{22}$ Far from being constrained by any notions of constitutionalism, the colonial state was highly authoritarian, and "control and coercion ... . were the hallmarks of the colonial legal order." 93 Further, such control and coercion were enabled by "instrumentalities of state power," which consisted of statutory (as distinguished from constitutional) laws and a "labyrinthine bureaucracy" through which colonial power and administration was exercised. ${ }^{94}$ This coercive legal order was characterized by "a complex maze of highly structured and coercive instruments" and "a degree of discretion that even courts sometimes found difficult to circumscribe."95

Africa's political elite quickly embraced this familiar legal order, and in many ways reinforced it. Further, this legal order largely remains intact in many African countries, despite decades of democratization experiments. This may explain why careful observers of

87. H. Kwasi Prempeh, Africa's “Constitutionalism Revival": False Start or New Dawn?, 5 INT'L J. CoNST. L. 469, 474 (2007).

88. See H.W.O. Okoth-Ogendo, Constitutions Without Constitutionalism: Reflections on an African Political Paradox, in Constitutionalism aND DEMOCRacY: TRANSITIONS IN THE CONTEMPORARY WORLD 65, 68 (Douglas Greenberg et al. eds., 1993).

89. Julius Nyerere, How Much Power for a Leader, 7 AFR. REP. 7 (1962).

90. Prempeh, supra note 87 , at 480 .

91. Okoth-Ogendo, supra note 88, at 70.

92. See id.

93. Id. at 69 .

94. See id. at 69-71.

95. Id. at 77. 
African politics, such as Prempeh, are worried that the imperial presidency has survived, despite the "precedent-setting changes to Africa's political and constitutional landscape."96 Prempeh laments that "Africa's current presidents may be term-limited, but by all accounts they have not yet been tamed." 97 Further, the president exercises executive power through bureaucrats, which entails delegating broad powers to the latter. As a result, bureaucrats regulate the daily lives of citizens. The breadth and lack of effective regulation of these powers in practice means that the bureaucrats often act as they wish. According to Prempeh, for example, the typical citizen's encounter with bureaucrats is 'fraught with abuse of discretion, selective and ad hoc 'rule making,' opportunistic delays, extortion, and frustration."98

A "credible regime of administrative law" can be useful in preventing this rampant abuse of power.99 In this respect, administrative law should be seen as a means for the realization of day-to-day democracy, as it enables citizens to hold public agencies to account in the periods between elections. Furthermore, the need for suitable regimes of administrative law is now even more urgent given the impact of globalization processes. Unless mechanisms are established to ensure accountability to the public, these processes may exacerbate the abuse of discretion that characterizes the exercise of power in much of Africa. Indeed, empirical research indicates that many Africans now acknowledge the limitations of ballot box democracy. ${ }^{100}$ In particular, they "do not . . . believe that elections have been particularly effective at securing political accountability" and do not see any role for themselves even "when it comes to asserting control over elected leaders in the long intervals between elections."101

\section{Innovations in African Constitutionalism}

Although the story of African constitutionalism has so far been disappointing in some respects, there is reason to be cautiously optimistic. This optimism is embodied in innovations such as the constitutionalization of the rule of law; the right to fair administrative

\footnotetext{
96. Prempeh, supra note 86 , at 110 .

97. Id.

98. H. Kwasi Prempeh, Marbury in Africa: Judicial Review and the Challenge of Constitutionalism in Contemporary Africa, 80 TUL. L. REV. 1239, 1302 (2005).

99. Id.

100. See, e.g., Michael Bratton \& Carolyn Logan, Voters but not Yet Citizens: The Weak Demand for Political Accountability in Africa's Unclaimed Democracies 2 (Afrobarometer, Working Paper No. 63, 2006).

101. Id. at iv.
} 
action and social and economic rights; and the establishment of institutions of horizontal accountability such as ombudsmen, human rights bodies, and anti-corruption bodies. The South African Constitutional Court is also leading the way in introducing novel remedies such as the structural interdict, which facilitates the implementation of constitutional prescriptions of social and economic rights, thereby enhancing the prospects of realizing meaningful democracy. Equally important, legislatures and judiciaries are being liberated from the shackles of the imperial presidency, making it possible for them to play their constitutional roles effectively.

\section{The Right to Fair Administrative Action}

A number of countries have now constititutionalized the right to fair administrative action. This idea was first embraced by Namibia in 1990 , and has since been adopted by South Africa and Kenya. Namibia's Constitution of 1990 provides that "[a]dministrative bodies and administrative officials shall act fairly and reasonably." 102 Further, the South African ${ }^{103}$ and Kenyan ${ }^{104}$ Constitutions respectively provide that "[e]veryone has the right to administrative action that is lawful, reasonable and procedurally fair." The inclusion of a similar provision in Zimbabwe's draft Constitution suggests that the idea of fair administrative action is gaining acceptance in other African countries. ${ }^{105}$

The idea behind this constitutional right is that the "[l]egal regulation of public power should include judicial review of administrative action as well as a range of procedures and institutions to ensure good governance."106 According to Hugh Corder, these procedures and institutions include,

genuinely consultative and participatory rule-making and decision-making procedures, accessible to the people affected; . . . a duty upon those exercising all forms of public power to give reasons for decisions ... . ; open government, access to official information and the minimisation of the scope of official secrets legislation; maximum feasible access to administrative justice,

102. ConstituTION, art. 18 (1990) (Namib.).

103. S. AFR. CONST, art. $33,1996$.

104. Constitution, art. 47 (2010) (Kenya).

105. DRAFt Constitution, art. 4.18 (2012) (Zimb.).

106. Hugh Corder, Reinventing Administrative Law in South Africa, in SUNRISE OR SunseT?: AdministRative LaW in The NeW Millennium 100, 103 (Chris Finn ed., 2000). 
including class actions, a broad definition of legal standing and the provision of adequate legal services; [and] the training of public servants [and the public] in the principles of good governance. ${ }^{107}$

The extent to which the right to fair administrative action will enhance the legal regulation of power in Africa will, among other things, depend on the willingness of judiciaries to interpret the term "administrative action" expansively. In an effort to ensure that courts do not unreasonably interfere with policy-making and executive decision-making, the South African Constitutional Court has drawn a distinction between executive and administrative action, stating that it would be reluctant to review the former. ${ }^{108}$ In President of the Republic of South Africa v. South African Rugby Football Union (SARFU), for example, the court held that the President's decision to appoint a commission of inquiry to investigate the administration of rugby was executive rather than administrative action. ${ }^{109}$ It reasoned that " $\left.t \mathrm{t}\right] \mathrm{he}$ relevant power was political in character, akin to a prerogative power, and it did not involve the implementation of legislation, which is the hallmark of administrative action."110

Nevertheless, this interesting case raises the question of whether executive action is, or should be, amenable to judicial review. Again, the approach taken by the South African Constitutional Court is instructive. In cases such as Pharmaceutical Manufacturers Association of South Africa: In re Ex parte application President of the Republic of South Africa,111 and Fedsure Life Assurance v. Greater Johannesburg Metropolitan Council,112 it has demonstrated willingness to subject matters of "high-policy" and executive action to judicial review. In Fedsure, it read Article 33(1) of the South African Constitution as constitutionalizing the principle of legality, which in its view formed part of the rule of law and expressed the idea that "the exercise of public power is only legitimate where lawful."113 Also, in Pharmaceutical Manufacturers, the Court reasoned that the rule of law requires "that

107. $I d$.

108. See generally Cora Hoexter, The Principle of Legality in South African Administrative Law, 4 MACQUARIE L.J. 165 (2004) (Austl.).

109. President of the Republic of S. Afr. v. S. Afr. Rugby Football Union 2000 (1) SA 1 (CC) (S. Afr.).

110. Hoexter, supra note 108 , at 175 .

111. See Pharm. Mfrs. Ass'n of S. Afr.: In re Ex parte Application President of the Republic of S. Afr. 2000 (2) SDA 674 (CC) (S. Afr.).

112. See Fedsure Life Assurance v. Greater Johannesburg Transitional Metro. Council 1999 (1) SA 374 (CC) (S. Afr.).

113. Hoexter, supra note 108 , at 181. 
the exercise of public power by the executive and other functionaries should not be arbitrary. Decisions must be rationally related to the purpose for which the power is given."114

The courts of other African countries should emulate this approach by treating the rule of law as a foundational value of the constitutional order. As Cora Hoexter has argued, the principle of legality, which forms part of the rule of law, is "a wonderfully useful and flexible device ... [in the sense that it] acts as a kind of safety net, catching exercises of public power that do not qualify as administrative action." 115 In her view, this principle tells us "that all exercises of public power must comply with standards such as lawfulness, reasonableness and fairness." 116 Indeed, a number of the post-1990 African Constitutions now make some reference to the rule of law. For example, Kenya's Constitution recognizes "the aspirations of all Kenyans for a government based on . . . the rule of law."117 Perhaps even more important, this Constitution establishes the rule of law as one of the "national values and principles of governance."118 It remains for the courts to give it effect so that the exercise of public power in Kenya can be regulated adequately.

It will also be necessary to educate "administrators as to their duties under the law and of the public as to their rights vis a vis [sic] the administration."119 In South Africa's case, it has long been proposed that an Administrative Review Council should be established to facilitate such education as part of its function of regulating the implementation of statutes enacted to give effect to the right to fair administrative action. 120 This function could also be performed by ombudsmen, such as Kenya's Commission on Administrative Justice, which has been established recently pursuant to requirements of the new Constitution. ${ }^{121}$

\section{Social and Economic Rights}

Another significant innovation is the constitutionalization of social and economic rights in various countries, since it can facilitate the

114. Pharm. Mfrs. Ass'n of S. Afr.: In re Ex parte Application President of the Republic of S. Afr. 2000 (2) SDA 674 (CC) at 67 para. 85 (S. Afr.).

115. Hoexter, supra note 108, at 183.

116. Id. at 185 .

117. Constituton, pmbl. (2010) (Kenya).

118. Id. art. 10.

119. Corder, supra note 106, at 108.

120. Id.

121. See The Commission on Administrative Justice Act, No. 23 (2011) (Kenya). 
attainment of social justice and thereby enhance the quality of democracy in Africa. For example, the Constitution of South Africa of 1996 gives everyone the right to have access to adequate housing, health care services, sufficient food and water, and social security. ${ }^{122}$ Further, it requires the state to "take reasonable legislative and other measures, within its available resources, to achieve the progressive realisation" of these rights. ${ }^{123}$ In addition, the Constitution of Kenya of 2010 gives every person the rights to "the highest attainable standard of health," accessible and adequate housing, reasonable standards of sanitation, freedom from hunger, clean and safe water in adequate quantities, and social security and education. ${ }^{124}$ Although Kenya's Constitution does not expressly impose obligations on the state to take measures to ensure their realization, it nevertheless provides that general rules of international law and treaties ratified by Kenya form part of the law of Kenya. Therefore, it can be expected that courts will require the executive to facilitate the progressive realization of social and economic rights, as required by the International Covenant on Economic, Social and Cultural Rights, which Kenya has ratified.

These provisions on social and economic rights are buttressed by provisions in the same Constitutions which guarantee all individuals "the right to equal treatment, including the right to equal opportunities in political, economic, cultural and social spheres."125 Further, these Constitutions mandate the state to establish affirmative action programs designed to ensure that minorities and marginalized groups are represented in governance. ${ }^{126}$

If implemented, these constitutional prescriptions can facilitate the realization of equality and inclusive citizenship. This would be a particularly desirable result, as it would help to eradicate the political manipulation of perceptions of marginalization and exclusion that have often contributed to inter-ethnic and racial conflicts in much of Africa, which have been exacerbated by globalization processes such as privatization. Eradicating such perceptions would foster a sense of nationhood without which meaningful democracy cannot thrive.

However, realizing the foregoing constitutional prescriptions is likely to be a difficult task for two reasons. First, the Constitutions in question, of which Kenya's is a good example, often do not provide formulae for reconciling competing claims of discrimination. In the absence of such formulae, a number of questions arise. For example, are

122. S. AFR. CONST., $1996 \S \S 26-27$.

123. Id. $\S 27(2)$.

124. Constitution, art. 43 (2010) (Kenya).

125. Id. art. 27(3).

126. See, e.g., id. art. 56. 
claims of discrimination based on ethnicity and disability subordinate to those based on gender? Further, how should governmental efforts to redress the three categories of discrimination be reconciled? It cannot plausibly be the case that one category of discrimination is more deserving of resolution than the others. In fact, if we privilege one category of discrimination, we risk undermining the legitimacy of its resolution.

Second, depending on what approach the courts take regarding claims of infringement on social and economic rights, they could either be accused of usurpation or abdication. ${ }^{127}$ One view holds that courts lack the legitimacy and institutional competence to interfere with the political branches' "conception and implementation of social and economic policies on which individuals' enjoyment of health, education, housing etc [sic] necessarily depend."128 According to an alternate view, the fact that social and economic rights are expressly recognized in a constitutional document as justiciable legal rights mandates that the courts legitimately intrude into the domain of the political branches and provide effective remedies for individuals whenever their rights are violated.129 If they fail to do so, it is argued that they would be abdicating their constitutional responsibility. 130

Administrative law can contribute to the resolution of both difficulties. Administrative law principles such as "proportionality" can contribute to the reconciliation of competing claims of discrimination. In Kenya, for example, the Constitution mandates the Government to establish affirmative action programs that will address discrimination and exclusion on the basis of gender, disability, and ethnicity. ${ }^{131}$ Unfortunately, it fails to provide a formula for reconciling these competing claims of discrimination. The principle of proportionality could be instrumental in reconciling these claims. Additionally, administrative principles such as "reasonableness" can contribute to the realization of social and economic rights. In this respect, the approach of South Africa's Constitutional Court is again instructive, even if it has been accused of abdication by various commentators. ${ }^{132}$ Its approach is very much rooted in the methodology of administrative law. In

127. See, e.g., Octavio L. M. Ferraz, Between Usurpation and Abdication? The Right to Health in the Courts of Brazil and South Africa, SOC. SCI. RES. NETWORK 20 (Aug. 20, 2009), available at http://ssrn.com/abstract $=1458299$.

128. Id. at 1 .

129. See id. at 3.

130. See id.

131. Constitution, art. 56 (2010) (Kenya).

132. See, e.g., Katharine G. Young, A Typology of Economic and Social Rights Adjudication: Exploring the Catalytic Function of Judicial Review, 8 INT'L J. CONST. L. 385, 394 (2010). 
successive cases, ${ }^{133}$ South Africa's Constitutional Court has adopted a policy of evaluating the reasonableness of policies promulgated by the government to facilitate the realization of social and economic rights. For the Court to consider state measures reasonable, "they must aim at the effective and expeditious progressive realisation of the right in question, within the states [sic] available resources for implementation." 134 Further, "[t]he measures must be comprehensive, coherent, inclusive, balance[d], flexible, transparent, be properly conceived and properly implemented, and make short, medium and long-term provision for those in desperate need or in crisis situations."135 In Government of the Republic of South Africa $v$. Grootboom, for example, the Court held that the government's housing program was unreasonable because it did not make reasonable provision for those in desperate need of housing. ${ }^{136}$

A major advantage of this approach is that it facilitates the democratization of the political decision-making process. Therefore, if the views of any particular affected individuals or groups have not been sought and included in the policy-making process, then the government will be required to accommodate such interests and reconsider its policy. The reasonableness approach can "place onerous demands on government bodies."137 This approach ensures that the political branches remain the primary locus of social and economic policy decision-making, as they should, whilst the courts ensure that the political process respects "the right of all citizens to equal participation in the process of deliberation."138 This "democracy strengthening role"139 of the courts would be particularly useful in Africa where the political process is all too often "deaf to the voices and rights of some individuals and groups in society." 140 Further, this approach enables the courts to

133. See, e.g, Minister of Health v. Treatment Action Campaign 2002 (5) SA 721 (CC) (S. Afr.); Gov't of the Republic of S. Afr. $v$. Grootboom 2001 (1) SA 46 (CC) (S. Afr.); Soobramoney U. Minister of Health (KwaZulu-Natal) 1998 (1) SA 765 (CC) (S. Afr.).

134. Lilian Chenwi, Putting Flesh on the Skeleton: South African Judicial Enforcement of the Right to Adequate Housing of Those Subject to Evictions, 8 HUM. RTS. L. REV. 105, 119 (2008).

135. $I d$.

136. Gov't of the Republic of S. Afr. v. Grootboom 2001 (1) SA 46 (CC) at 9 para. 11 (S. Afr.).

137. Anashri Pillay, Reinventing Reasonableness: The Adjudication of Social and Economic Rights in South Africa, India and the United Kingdom 3 (2011) (unpublished $\mathrm{Ph} . \mathrm{D}$. thesis, University College London) (on file with Faculty of Laws, University College London Library).

138. Ferraz, supra note 127 , at 17 .

139. See Sandra Fredman, Human Rights Transformed: Positive Rights and Positive DUTIES 100 (2008).

140. Ferraz, supra note 127 , at 17. 
avoid undermining their legitimacy by attempting to resolve deeply polycentric controversies concerning whose needs should "receive priority over the competing needs of other individuals dependent on the same scarce resources." 141

The South African courts have also adopted an unusual approach to enforcing their orders in the context of social and economic rights. In various cases, they have issued structural interdicts, which allow them to participate in the implementation of their orders. ${ }^{142}$ The structural interdict, which can be traced back to school desegregation cases in the United States, such as Brown v. Board of Education, ${ }^{143}$ seeks to achieve structural institutional reforms as opposed to merely compensating for past wrongs. ${ }^{144}$ For example, if the problem is that the government, in making a housing policy, has failed to take into account the views of those in desperate need of housing (as in Grootboom), then the court would issue a structural interdict requiring the government to indicate the measures it would institute to address the problem, and delineating how it would ensure the participation of the affected parties. Further, the court could also ask the government to indicate timelines within which it intends to address the problem. The structural interdict allows the court to retain jurisdiction, and actively participate in enforcing its orders. ${ }^{145}$ The retention of jurisdiction is important because it enables the aggrieved parties to go back to the court for assistance should the government fail to keep its promises. ${ }^{146}$ Indeed, it has enabled the South African courts to bring the litigating parties together (as well as third parties) so that they can resolve the problem at hand through negotiation or mediation. ${ }^{147}$

Given the existing levels of inequality in many African countries, which have been exacerbated by globalization, the structural interdict can be a particularly useful tool in ensuring that disadvantaged individuals and groups enjoy the social and economic rights that have been promised in many Constitutions. Invariably, such individuals and groups do not have the resources to engage the government in court battles. Therefore, it is important that when issues of social and economic rights do reach the courts, they are fully litigated with a view to finding lasting institutional solutions. As the South African cases

141. Id. at 9 .

142. See Young, supra note 132 .

143. Brown v. Bd. of Educ., 349 U.S. 294 (1955).

144. See Christopher Mbazira, Litigating Socio-Economic Rights IN South AFRICA: A CHOICE BETWEEN CORRECTIVE AND DISTRIBUTIVE JUSTICE 176 (2009).

145. Id. at 176-77.

146. See id. at $181-83$.

147. See id. at 183-84. 
demonstrate, the structural interdict facilitates such resolution by ensuring that the courts remain engaged until the issue at hand is resolved. ${ }^{148}$ It also facilitates the attainment of solutions that take into account the views of those affected (or likely to be affected) by governmental decision-making. In other words, the prevalence of inequality means that the judge should not just be a neutral arbiter. On the contrary, establishing the conditions under which democracy can thrive entails, inter alia, active judicial management of disputes, particularly those involving the realization of social and economic rights. ${ }^{149}$

\section{Institutions of Horizontal Accountability}

Guillermo O'Donnell has defined institutions of horizontal accountability as "state agencies that are legally enabled and empowered, and factually willing and able, to take actions that span from routine oversight to criminal sanctions or impeachment in relation to actions or omissions by other agents or agencies of the state that may be qualified as unlawful."150 He argues that these institutions can only be effective if they cooperate rather than "operate in isolation."151 These institutions enhance the quality of democracy. ${ }^{152}$ Arguably, democracy is not viable where they are absent or weak. ${ }^{153}$ In my view, institutions of horizontal accountability are now taking shape in many African countries, even if their effectiveness continues to be undermined by an authoritarian statutory order.

In the recent past, a number of African countries have established regulatory agencies to facilitate the accountability of privatization processes. The following analysis is based on the experience of the East African countries of Kenya, Tanzania, and Uganda. ${ }^{154}$ In those countries, various agencies have been established to regulate the provision of privatized public functions such as water, sanitation, and security. These three countries have also established human rights

148. See MBAZIRA, supra note 144 , at $180-83$.

149. See, e.g., Port Elizabeth Municipality v. Various Occupiers 2005 (1) SA 217 (CC) at para. 36 (S. Afr.).

150. Guillermo O'Donnell, Horizontal Accountability in New Democracies, in THE Self-Restraining State: Power and ACCOUnTability In New Democracies 29, 38 (Andreas Schedler et al. eds., 1999).

151. Id. at 39.

152. See Larry Diamond et al., Introduction to The SeLF-RESTRAINING STATE: Power AND ACCOUNTABILITY IN NEW DEMOCRACIES, supra note 150, at 1,2.

153. See id. at 2.

154. See generally Akech, supra note 50 (exploring the role of democracy in the process of privatization in Kenya, Uganda, and Tanzania). 
institutions which function as additional oversight mechanisms insofar as they have broad mandates to investigate and report on human rights violations. All in all, the mechanisms adopted by these institutions are largely progressive, even if these countries continue to embrace the Westminster approach of ministerial control, which obliges the agencies to work under the direction and control of the relevant minister. ${ }^{155}$ This requirement often works to the detriment of the operational autonomy of these agencies.

All too often, these agencies continue to lack autonomy from the executive, which in many cases retains the unregulated power to appoint and dismiss their members. In Nigeria, for example, President Obasanjo used his powers of appointment and dismissal to stop his bitter rival, Vice President Abubakar Atiku, from gaining the nomination of the ruling party. ${ }^{156}$ The Independent National Electoral Commission, which was "a virtual appendage of the presidency," issued "politically motivated corruption indictments in order to disqualify targeted candidates," such as Vice President Atiku. ${ }^{157}$ Likewise, anti-corruption authorities remain ineffective due to executive control and a lack of political will to fight corruption.

Although democracy needs institutions of accountability, a question arises as to how they are to be held to account. That is, who will guard the guardians? This is the fundamental question posed by bureaucracy, which is "typically insulated from state officials and the people," and which can therefore be accused of being undemocratic. ${ }^{158}$ Put differently, how can citizens ensure that agencies of the executive are not only effective, but also do not abuse their powers?

In this regard, Kenya, Tanzania, and Uganda have made useful legislative efforts to facilitate public scrutiny of the workings of these agencies. Of the three countries, Tanzania has adopted the most innovative measures to facilitate the democratic governance of regulatory agencies. Tanzania has established Consumer Consultative Councils and also requires the Energy and Water Regulatory Authority to consult the public through an annual program. ${ }^{159}$ Tanzania has also done the most to ensure that the membership of regulatory commissions such as the Commission for Human Rights and Good Governance is

155. See AKECH, supra note 50.

156. Rotimi T. Suberu, Nigeria's Muddled Elections, in Democratization IN AFriCA: Progress AND Retreat 121, 123 (Larry Diamond \& Marc F. Plattner eds., 2d ed. 2010).

157. Id. at $124,129$.

158. Diamond et al., supra note 152 , at 1,3 .

159. The Energy and Water Utilities Regulatory Authority Act, (2001) No. $11 \S 30$ (Tanz.). See also The Tanzania Civil Aviation Authority Act, (2003) No. $10 \S 30$ (establishing a Consumer Consultative Council). 
broadly representative of society. Here, members of the Commission are appointed through a democratic process that is calculated to enhance the legitimacy of the Commission in the eyes of the citizenry. ${ }^{160}$ Kenya, Uganda, and other African countries can learn much from Tanzania's innovative experiments in deliberative democracy.

Although these developments in Tanzania are encouraging, significant obstacles to meaningful public participation in the decision-making processes of regulatory or administrative agencies remain. Perhaps the most significant obstacle here is the fact that there is no uniformity in the rule-making procedures of these agencies, the effect of which is that the public often does not know when and how to participate in agency decision-making. In Kenya, for example, different agencies employ different procedures in their rule-making. The governing statutes simply give the agencies or the government minister to whom they are answerable, the power to make rules or regulations "for the better carrying into effect of the provisions" of the statute. ${ }^{161}$ In the absence of a set of minimum standards that administrative agencies can use, some agencies employ fairly elaborate procedures while others simply do not care about public participation. To seal this public participation gap, countries like Kenya can learn from South Africa's Promotion of Administrative Justice Act, which prescribes a set of minimum standards that administrative agencies must meet to ensure that their actions are procedurally fair. ${ }^{162}$ In the case of administrative action affecting the public, for example, this act requires administrators to hold a public inquiry, follow a notice and comment procedure, do both, or follow a different procedure provided it is fair. ${ }^{163}$

However, the citizenry can only take advantage of expanded democratic spaces if they are sufficiently resourced. It is in this respect that legal empowerment initiatives become crucial. Regulatory processes, which continue to proliferate in African countries, now significantly affect the lives and liberties of citizens. Therefore, legal empowerment initiatives that will enable the people to better interact with regulatory agencies need to be formulated and implemented. Such initiatives should include legal literacy training, legal assistance, and public interest litigation. ${ }^{164}$ In particular, the capacities of

160. The Commission for Human Rights and Good Governance Act (2001) No. $16 \S 7.2$ (Tanz.).

161. E.g., Kenya National Commission on Human Rights Act, (2011) No. $14 \S 56$.

162. Promotion of Administrative Justice Act 3 of 2000 (S. Afr.).

163. Id. at $\S 4(1)$.

164. LORENZO COTULA, LEGAL EMPOWERMENT FOR LOCAL RESOURCE CONTROL: SECURING LOCAL RESOURCE RIGHTS WITHIN FOREIGN INVESTMENT PROJECTS IN AFRICA 22 (2007). 
disadvantaged and vulnerable groups need to be enhanced-by state and non-governmental organizations-so that they can make better use of the democratic spaces that the institutionalization of the right to administrative justice (through the enactment of procedural fairness standards) would create. ${ }^{165}$ While it can no doubt be expected that getting such groups to participate meaningfully in regulatory discourses will be fraught with challenges, deliberative democracy initiatives elsewhere in the world demonstrate that the establishment of participatory sphere institutions may greatly enhance the practice of democracy. 166

\section{The Liberation of Legislatures and Judiciaries}

Ongoing democratization initiatives have enhanced the autonomy of African legislatures. ${ }^{167}$ For example, a number of these legislatures have been granted independence from the executive. ${ }^{168}$ Joel D. Barkan observes that a small number of African legislatures "have become real players in the policy-making process and thus institutions of countervailing power vis-à-vis the executive."169 Nevertheless, increased autonomy will require increased accountability if these legislatures are to contribute to the development of responsive governance. In this respect, the experience of Kenya's legislature is instructive. Arguably, Kenya's legislature is one of the most powerful on the continent today. ${ }^{170}$ Unfortunately, "there are definite concerns that [this legislature] is not sufficiently accountable, especially in the manner in which legislators have exercised their 'collective powers' of policymaking, legislating and overseeing the executive branch."171 Here, "the absence of effective accountability mechanisms in the legislature has produced two undesirable results."172

165. See id. at 44 (discussing the tools of legal empowerment).

166. See generally SPACES FoR Change?: THE POLITICS OF CitIZEN PARTICIPATION IN NEW DEMOCRATIC ARENAS (Andrea Cornwall \& Vera Schattan Coelho eds., 2007) ("[T]his book provides rich and compelling empirical case studies of the dynamics of democratic participation, especially in relation to 'new democratic arenas' at the local level.").

167. E.g., Joel D. Barkan, African Legislatures and the "Third Wave" of Democratization, in LEGISLATIVE POWER IN EMERGING AFrICAN DEMOCRACIES, supra note 49 , at $1,1-2$.

168. See id.

169. Id. at 2 .

170. See, e.g., Joel D. Barkan \& Fred Matiangi, Kenya's Tortuous Path to Successful Legislative Development, in Legislative PoWer in EMERGING AFriCAN DEMOCRACIES, supra note 49 , at 33 .

171. Migai Akech, Abuse of Power and Corruption in Kenya: Will the New Constitution Enhance Government Accountability?, 18 IND. J. GLOBAL LEGAL STUD. 341, 365 (2011).

172. Id. 
First, legislators are vulnerable to influence from special interest groups, which jeopardizes the ability of the legislature to safeguard the public interest. Second, the legislature's ability to hold the executive accountable is questionable because its committees, which form a critical part of its arsenal of oversight instruments, often consist of legislators against whom credible allegations of corruption have been made, and who cannot therefore be expected to be genuine champions of the public interest. ${ }^{173}$

"In the recent past, the legislature has arguably been unduly influenced by special interest groups in exercising its lawmaking power, as the enactment of the Tobacco Control Act of 2007 illustrates."174 "Furthermore, the legislature has not only enacted unconstitutional laws . . . but has also failed to amend laws that have been declared unconstitutional." 175 These examples demonstrate that the legislature is not only prone to the undue influence of special interest groups, but may also be abusing its collective power. While it is to be expected that different interest groups will legitimately lobby the legislature to enact favorable policies and laws, there should be procedural mechanisms to ensure that interest groups seeking specific legislative outcomes do not subvert the public interest. "Such mechanisms include those that regulate lobbying, conflicts of interest, misconduct, and even corruption in the legislature."176 Unfortunately, these mechanisms have either been deficient or absent altogether.

Allegations of corruption have also been leveled against the Parliamentary Service Commission, which is the bureaucracy that administers the Kenyan legislature. ${ }^{177}$ Among other things, this body provides services and facilities to ensure effective and efficient running of the legislature. It has been accused of all manner of ills, including "irregular tendering processes, . . . and irregular recruitment, remuneration and promotion practices." 178 Such maladministration can only be dealt with if the Parliamentary Service Commission is treated

173. Id.

174. Id. at 371 .

175. Id.

176. Id.

177. See, e.g., Okiya Omtatah Okoiti, Why We Want the Parliamentary Service Commission Scrapped, SUKUMA KENYA (Jan. 14, 2009, 3:29 PM), http://sukumakenya.blogspot.com/2009/01/why-we-want-parliamentary-service.html.

178. E.g., Should the Parliamentary Service Commission be Disbanded?, MzaLENDo (Nov. 12, 2011), http://www.mzalendo.com/2011/11/12/should-the-parliamentary-servicecommission-be-disbanded/. 
like any other administrative body by subjecting its administrative action to judicial review and oversight by an ombudsman.

A similar approach should be adopted in regulating judicial power. Although the liberation of Africa's judiciaries from executive domination remains slow, a number of countries have made progress. In Kenya, for example, the Constitution now establishes due process mechanisms to ensure that the process of removing judges from office is transparent, impartial, and fair. ${ }^{179}$ In all likelihood, certainty in the exercise of the power to dismiss judges will enhance security of tenure and independence of judges. Further, this Constitution grants the judiciary autonomy from the executive. ${ }^{180}$ It also establishes an autonomous Judicial Service Commission to "promote and facilitate the independence and accountability of the judiciary and the efficient, effective and transparent administration of justice."181 While securing the decisional autonomy of judges and the independence of the judiciary from external actors such as the executive is no doubt important, Kenya's experience is arguably more useful in terms of how African countries can handle factors internal to the judiciary that often undermine the decisional independence of judges.

Throughout common law Africa, the Chief Justice, who is the head of the judiciary, typically wields wide-ranging but unregulated powers. ${ }^{182}$ These immense powers include determining which judges hear what cases, determining where litigants can file their cases, supervising and disciplining judicial officers, allocating office space and housing, supplying judicial officers with motor vehicles, transferring judicial officers from one geographic station to another, and initiating the process of removing judges. ${ }^{183}$ Because the exercise of these powers is not usually circumscribed, it has often been abused to the detriment of judicial independence and accountability. Thus, judges confronted with these powers may be inclined to do the bidding of the Chief Justice. Unsurprisingly, many judges quake in the presence of the Chief Justice.

Kenya's Constitution seeks to resolve this problem by dispersing judicial authority. Although the Chief Justice remains the head of the judiciary, the Constitution establishes three superior courts (in addition

179. Constitution, art. 168 (2010) (Kenya).

180. Id. art. 166.

181. Id. art. 172.

182. See, e.g., Migai Akech \& Patricia Kameri-Mbote, Kenyan Courts and Politics of the Rule of Law in the Post-Authoritarian State,18 E. AFR. J. PEACE \& HUM. RTS. 357, 369 (2012).

183. See, e.g., Republic of KeNYa, Final Report of the TASK Forde on JUd. REFormS $61-62$ (2010) available

http://www.kenyalaw.org/Downloads/Final\%20Report\%20of\%20the\%20Task\%20Force\%20 on\%20Judicial\%20Reforms.pdf. 
to various subordinate courts): the Supreme Court, the Court of Appeal, and the High Court. ${ }^{184}$ It also establishes the offices of Deputy Chief Justice (as the deputy head of the judiciary) and Chief Registrar of the Judiciary. The Chief Registrar of the Judiciary is the judiciary's chief administrator and accounting officer pursuant to Article 161,185 and administers the Judiciary Fund established by Article 173 to enhance the financial autonomy of the judiciary. ${ }^{186}$ It further provides that the Chief Justice will preside over the Supreme Court, while the Court of Appeal and the High Court will each be presided over by a judge, who will be elected by the judges of these courts from among themselves pursuant to Article $164 .{ }^{187}$ These provisions greatly curtail the powers of the Chief Justice, thereby reducing his ability to undermine the decisional independence of judges. In order to realize the potential of these provisions, though, it will be necessary to formulate procedures for their implementation so that the exercise of powers, such as allocating cases, effecting transfers of judicial officers, and disciplining judicial officers can be subjected to fair, certain, and democratic procedures. Again, as in the case of the bureaucracy of the legislature, it will be necessary to subject the administrative decisions of judicial councils (such as Kenya's Judicial Service Commission) and bureaucracies (such as Kenya's Office of the Chief Registrar of the Judiciary) to judicial review and oversight by an ombudsman.

\section{Regulating Private Power}

African judiciaries have begun to scrutinize the exercise of private power, particularly where private bodies exercise public functions. In this regard, the South African courts are leading the way. In the case of AAA Investments (Pty) Ltd. v. Micro Finance Regulatory Council, for example, the South African Constitutional Court held that private bodies must comply with principles of administrative justice when they exercise administrative powers. 188 The court responded to the question of whether a private and voluntary body with the power to make rules regulating the micro-loan industry exercised public power whenever it made rules. The court reasoned that because the Council regulated in the public interest and in the performance of a public duty, its decisions and rules were subject to constitutional principles such as the principle

184. Constitution, arts. 163-65 (2010) (Kenya).

185. Id. art. 161(2)(b), (c).

186. Id. art. 173(1).

187. Id. arts. 163(1)(a), 164(2), 165(2).

188. AAA Invs. (Proprietary) Ltd. v. Micro Fin. Regulatory Council2006 (11) BCLR 1255 (CC) at para. 11 (S. Afr.). 
of legality. 189 This is a progressive development that ought to be emulated by other judiciaries, given the proliferation of privatization initiatives in the continent.

African judiciaries should also consider regulating purely private bodies that exercise de facto powers. This need arises especially in the sporting arena where African athletes are increasingly subject to the rules of transnational sports organizations and federations that govern international sport. The International Football Federation (known as FIFA), the International Cricket Council (ICC), and the International Olympic Committee (IOC) are good examples. These organizations largely operate outside the purview of national and international law, and are governed by their rulebooks and Constitutions as autonomous private entities. ${ }^{190}$

While membership in these organizations is voluntary, they invariably monopolize their sports and athletes are thus compelled to become members if they want to participate in the regulated sports. Therefore, these organizations are extremely powerful and their decisions "can have profound effects on the careers of players." 191 "For instance, they can suspend or ban players from the sport, thereby depriving them of a livelihood." 192 While such power may be necessary to ensure that the spirit of fair play prevails in sports, it is patently capable of being abused. Unfortunately, when such power is abused, the affected athletes are often at a dead end because national courts are reluctant to intervene, interpreting their relationship as a private affair governed by contract and outside the purview of public law. Further, the only recourse these athletes usually have is to appeal to the Court of Arbitration for Sport, which is based in Switzerland. This makes the pursuit of justice an exceedingly expensive affair. Indeed, the fact that this court does not have branches in Africa usually denies them access to justice.

This is the fate that befell Maurice Odumbe, a star cricketer and captain of Kenya's national cricket team in $2004 .{ }^{193}$ Odumbe was found guilty in an investigation authorized by the ICC and conducted by the Kenya Cricket Association (KCA) of having engaged in "inappropriate conduct" with a bookmaker and was subsequently banned from the

189. Id. at para. 29.

190. See Ken Foster, Is There a Global Sports Law?, 2 ENT. L. 1, 3 (2003).

191. Id. at 1 .

192. Migai Akech, The Maurice Odumbe Investigation and Judicial Review of the Power of International Sports Organizations, 6 ENT. SPORTS L.J. (2008), available at http:/go.warwick.ac.uk/eslj/issues/volume6/number2/akech (using the case of Maurice Odumbe to argue that the power of international governing bodies of sports should be regulated by national courts).

193. Id. 
game for five years. ${ }^{194}$ In an attempt to overturn this career-threatening ban, Odumbe applied for judicial review. The High Court of Kenya declined to entertain his application, reasoning that it would not issue judicial review orders against the ICC and the KCA since they were not "public bodies or persons performing public functions" and that his remedies lay in private law as this was a contractual dispute. ${ }^{195}$

In my view, however, judicial review provides an important tool for the national regulation of the exercise of the power of such International Sports Organizations (ISOs). National courts should not only intervene where the power of ISOs has been exercised unreasonably, but also where the rules and regulations of these organizations are unreasonable. But courts should draw the parameters of intervention carefully to ensure that they do not unduly interfere with the management of sport. They should strive to intervene only where the rules and regulations of ISOs are arbitrary, irrational, illegal, violate general principles of law, or cause economic damage to individuals. In addition, courts should intervene where ISOs interpret their rules and regulations unreasonably or wrongly. ISOs should not be allowed to be the sole interpreters of their rules and regulations. In the Odumbe case, for instance, there was sufficient justification for the High Court of Kenya to interfere with the decision of the ICC/KCA tribunal. The rule Odumbe is alleged to have violated was not only unreasonable and unduly punitive, but its application to the facts was equally unreasonable. ${ }^{196}$ One can only hope that when similar cases arise in the future African courts will be bold enough to intervene and stop private transnational organizations from abusing their power.

\section{CONCLUSION}

It is important for public law, especially administrative law, to pay attention to how globalization and domestic political processes interact. This is because globalization processes such as privatization and the growth of transnational modes of governance are characterized by the exercise of immense power which often adversely impacts the liberties and livelihoods of individuals who typically have no means of participating in the exercise of such power or holding it to account. In this respect, administrative law can be a useful instrument for

194. RePORT By Mr. Justice AHMEd EBRAHIM IN THE ENQUIRY Relating to MaURICE ODUMBE 30-31 (2004), available atin.yimg.com/icccricket/pdfs/odumbe_report_ aug2004.pdf.

195. Republic v. Kenya Cricket Ass'n, (2006), available at http://www.kenyalaw.org/ CaseSearch/view_preview.php?link=18430952626790132716501\&words=.

196. See Akech, supra note 192, at para. 6 . 
deepening democracy in African countries. Administrative law norms such as legality, reasonableness, procedural fairness, and proportionality can be used to regulate the exercise of both public and private power. African countries, therefore, need to establish and implement elaborate regimes of administrative law containing such principles and procedures.

Although administrative law has been poorly regarded in the governance frameworks of African countries, there have been encouraging developments in the recent past that could enhance its role in democratic governance. These developments include the constitutionalization of the rule of law; the right to fair administrative action and social and economic rights; and the establishment of institutions of horizontal accountability such as ombudsmen, human rights bodies, and anti-corruption bodies. In addition, legislatures and judiciaries are being liberated from the shackles of the imperial presidency. And some courts, such as South Africa's Constitutional Court, are now more willing to regulate the exercise of private power.

First, the principle of legality, which forms part of the rule of law, could facilitate judicial regulation of all kinds of power, including executive and administrative action. Second, administrative law can democratize political decision-making processes, thereby contributing to the realization of equality and inclusive citizenship, without which democracy cannot thrive. In this respect, African judiciaries can also contribute to the attainment of meaningful democracy by engaging in active judicial management, especially in cases involving the enforcement of social and economic rights. Further, administrative law principles such as proportionality can contribute to the reconciliation of competing claims of discrimination (such as those based on ethnicity, race, gender, or disability), which Constitutions such as those of Kenya and South Africa seek to redress. Third, administrative law can prescribe sets of minimum standards that administrative agencies, under the watch of ombudsmen, should meet so as to ensure that their actions are lawful, reasonable, and procedurally fair. In doing so, administrative law would enhance the accountability of these agencies. Fourth, administrative law can contribute to the democratization of the exercise of power within legislatures and judiciaries, thereby enhancing their effectiveness and legitimacy as institutions of countervailing power. Finally, administrative law can facilitate the regulation of de facto private power, particularly the power of transnational organizations that operate outside the purview of national and international law.

Ultimately, the potential of administrative law to enhance democracy in Africa should be tested through empirical research. There 
is a need to document the interactions that ordinary citizens have with the exercise of public and private power, with a view to contributing to policy and legislative initiatives that seek to empower citizens to participate more effectively in democratic processes, and hold the exercise of power to account. In addition, although democratization has led to the establishment of institutions such as ombudsmen and judicial review, there is no documentation of whether (or how) these institutions are working. In any case, there has been no systematic study of the impact of administrative law in general and judicial review in particular on public administration. Accordingly, research on administrative law in African countries could, inter alia: (a) assess the rule-making and adjudication practices of governmental agencies with a view to establishing the extent to which they adhere to the principles of administrative law; (b) assess whether the public participate in the decision-making processes of governmental agencies and whether there are any obstacles to effective participation; and (c) assess whether, and how, administrative agencies are accountable to the public for their actions, including possible obstacles such as access to needed information, and whether judicial review and the ombudsman have an impact on the exercise of power. It is only through such empirical research that we can confidently gauge how the ordinary citizen is interacting with the processes of globalization. 
